\title{
Mycotoxins in feeds and their fate in animals: a review
}

\author{
Alexandros YIANNIKOURIS ${ }^{\mathrm{a}, \mathrm{b}}$, Jean-Pierre JOUANYa*

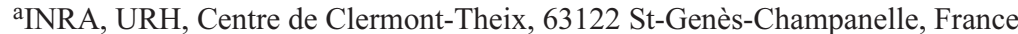 \\ bAlltech-France, 2-4 avenue du 6 juin 1944, 95190 Goussainville, France
}

(Received 8 November 2001; accepted 18 March 2002)

\begin{abstract}
Mycotoxins are secondary metabolites secreted by moulds, mostly belonging to the three genera Aspergillus, Penicillium and Fusarium. They are produced in cereal grains as well as forages before, during and after harvest, in various environmental conditions. Due to the diversity of their toxic effects and their synergetic properties, mycotoxins are considered as risky to the consumers of contaminated foods. Mycotoxin metabolism is complex and involves pathways of bioactivation and detoxification in both humans and animals. Detoxification occurs via biotransformation mediated by enzymes in the host cells and in the digestive microbial flora. Some of the toxins or their metabolites may become fixed in animal or human tissues. However, most are eliminated in the urine, faeces and milk. In animals, toxicity is generally revealed as chronic minor troubles and only rarely causes death. The presence of mycotoxins in feeds may decrease feed intake and affect animal performance. In addition, the possible presence of toxic residues in edible animal products (milk, meat, offal), may have some detrimental effects on human health. Maximum acceptable doses in feeds and milk have been set for certain mycotoxins by international authorities. The potential risks of mycotoxins may be controlled by checking plant material for fungal contamination, by improving methods of cultivation, harvest and storage, by eliminating or diluting toxins from the contaminated food or feeds, and by using adsorbents to reduce the bioavailability of toxins in the digestive tracts of animals. These measures will be assessed in the present paper.
\end{abstract}

\section{mycotoxins / feeds / ruminants / detoxification / rumen microbes}

Résumé - Les mycotoxines dans les aliments et leur devenir chez le ruminant. Les mycotoxines sont des métabolites secondaires produits par les moisissures appartenant principalement aux genres Aspergillus, Penicillium et Fusarium. Ces moisissures se développent sur les grains des céréales et dans les fourrages pendant la culture au champ, pendant la récolte et durant la période de conservation. Les mycotoxines sont souvent présentes en mélange et constituent un risque pour les consommateurs en raison de leur synergie. Le métabolisme des mycotoxines est complexe. Il implique chez l'homme et les animaux, des voies de bioactivation et de détoxication. La détoxication fait appel à des processus de biotransformation impliquant des enzymes de l'hôte et de l'écosystème microbien

*Correspondence and reprints

Tel.: 33 (0)4 736240 54; fax: 33 (0)4 736346 59; e-mail: jouany@clermont.inra.fr 
présent dans le tube digestif. Certaines des toxines ou de leurs métabolites peuvent être fixés dans les tissus animaux ou humains. Cependant, la majorité est éliminée dans l'urine, dans les fèces et dans le lait. La toxicité se manifeste généralement sous forme de troubles chroniques difficiles à identifier, et rarement par la mort de l'animal. La présence de mycotoxines dans les aliments diminue la plupart du temps les quantités d'aliments ingérés ainsi que les performances zootechniques des animaux. La présence de résidus toxiques dans les produits animaux destinés à la consommation humaine (lait, viande, abats) constitue un risque potentiel qu'il est nécessaire d'évaluer pour mieux répondre à la demande sociétale de sécurité dans la chaîne alimentaire. Des doses acceptables devront être définies pour les toxines les plus dangereuses. En parallèle, des moyens de contrôle devront être mis en place pour vérifier l'innocuité des produits alimentaires mis sur le marché. Le risque potentiel des mycotoxines peut être diminué en évitant la contamination des plantes par les moisissures au moment de leur culture, de leur récolte et de leur conservation. Il est également possible de réduire la concentration en toxines des plantes contaminées par dilution avec des aliments sains et par des traitements appropriés, et (ou) de limiter la biodisponibilité des mycotoxines par l'ajout de ligands spécifiques. Ces différents aspects seront traités dans le présent article.

mycotoxines / aliments / animaux / ruminants / lait / toxicité / sécurité alimentaire

\section{INTRODUCTION}

Following the recent crises on bovine spongiform encephalopathy, salmonellosis, listeriosis, the presence of pesticides or chemical compounds such as dioxins in food or feeds, the use of anabolic steroids in farm animals, and the use of GMO, consumers have become highly sensitive to the notion of food safety. The risks associated with infection and parasites are well understood, but the risks associated with the natural presence of toxins or their metabolites in animal feeds are mostly unknown. Most people consider that natural products are safe. However, contamination of human or animal food with natural toxins may result in a number of troubles and even severe diseases.

Moulds may grow on plants in the field or during the storage period. These fungi may produce toxins, which may have deleterious effects on humans or animals consuming the contaminated product. Such cases of poisoning may cause death in animals, but are rarely fatal in humans [59]. The history of humanity clearly shows that the mycotoxicological risk has existed since the very beginnings of organised agri- cultural production [62]. Some references to ergotism in the Old Testament [76] and fusariotoxins such as T-2 toxin and zearalenone are thought to be responsible for the decline of the Etruscan civilisation [77] and the Athenian crisis, which occurred in the Fifth Century B.C. [78]. Certain Egyptian tombs are also thought to contain ochratoxin A, responsible for the mysterious deaths of several archaeologists [62].

It was not until 1960 that the first cases of mycotoxicosis were demonstrated following an agricultural incident in Great Britain. More than 100000 turkeys died of severe liver necrosis and biliary hyperplasia caused by a family of molecules identified as aflatoxins. A large number of mycotoxins have since been discovered, the last major group of which, the fumonisins, was described in 1988.

There is also an indirect risk due to the carryover of toxins and their metabolites to edible animal products such as milk, meat, and eggs. In this article, we aim to review current knowledge concerning the risk to food safety due to the presence of mycotoxins in feed consumed by animals, particularly in dairy cows. Information not 
available for dairy cows will be given for other animal species.

\section{WHAT ARE MYCOTOXINS?}

Mycotoxins are produced by fungi or micromycetes according to four different pathways [45] involving secondary fungal metabolism, the bioconversion of plant compounds (dicoumarol), the reactivity of the plant to fungal aggression (coumestrol), and plant-fungus associations (for endophytic fungi) respectively.

Secondary metabolism differs from primary metabolism in the random nature of its activation, the diversity of the compounds formed, and the specificity of the strains involved. Secondary metabolism is not associated with cell growth, but instead generally responds to signals from the environment of the fungus. Whereas primary metabolism is common to all fungal species and interacts with the general metabolic pathways for the synthesis and catabolism of carbohydrates, lipids and proteins, secondary metabolism may be specific to a species, or even to a fungal strain and its genetic characteristics [85].

The fungal contamination of plants and the bio-synthesis of toxins depend on environmental conditions: the state of the health of the plant before harvest, meteorological conditions, harvesting techniques, delays and hydrothermal conditions before stabilisation for conservation.

Six groups of mycotoxins are produced by the three principal genera of fungi Aspergillus, Penicillium and Fusarium (Tab. I). Mycotoxins display a diversity of chemical structures, accounting for their different biological effects. Depending on their precise nature, these toxins may be carcinogenic, mutagenic, teratogenic, oestrogenic, neurotoxic or immunotoxic. In animals, five mycotoxins - aflatoxins (AFB1 and AFM1), ochratoxin A (OTA), moniliformin and sterigmatocystin - have been demonstrated to be carcinogenic. In humans, aflatoxins, and recently OTA (1993), have been classified as carcinogenic by the International Agency for Research on Cancer. Fumonisin B1 (FB1) is currently classified as a possible carcinogen and may soon be recognised as a proven carcinogen. Recent toxicological results for patulin (PAT) have also suggested that this toxin may present a health hazard.

\section{LEVEL OF CONTAMINATION OF RUMINANT FEED}

Forages and cereals naturally come into contact with fungal spores before, during and after harvest, and during transport and storage. Fungal growth is controlled by a number of physico-chemical parameters including the amount of free water $\left(a_{w}\right)$, temperature, presence of oxygen, nature of the substrate, and $\mathrm{pH}$ conditions [54]. Rodents, birds and insects may facilitate contamination by causing physical lesions on plants, providing a route of entry into the plant for fungal spores $[41,58]$. We still know very little about the factors on which the subsequent phase of toxinogenesis depends.

\subsection{Moulds and mycotoxins in fodder}

Contamination of grasses with endophytic fungi will not be considered in this paper.

Pastures in France have been shown to harbour fungi such as Claviceps which are responsible for ergotism, Pythomyces producing sporidesmin which causes facial eczema, Neotyphodium which causes dry gangrene, and Rhizoctonia producing slaframin which causes sialorrhea in ruminants [45]. The mould most frequently encountered in the field belongs to the genus Fusarium. Although this fungus principally infects cereals, it can also be found on forages in the field and after harvest. Depending on the species and environmental 
Table I. Fungi and their associated mycotoxins (the structures shown correspond to the molecules in bold typeface).

\begin{tabular}{|l|l|}
\hline \multicolumn{1}{|c|}{ Fungi } & \multicolumn{2}{|c|}{ Mycotoxins } \\
\hline $\begin{array}{l}\text { Aspergillus flavus, A. parasiticus, } \\
\text { A. nomius }\end{array}$ & Aflatoxins B1, $\mathrm{B} 2, \mathrm{G} 1, \mathrm{G} 2$ \\
\hline $\begin{array}{l}\text { Penicillium verrucosum, } \\
\text { Aspergillus clavatus }\end{array}$ & Ochratoxin A \\
\hline $\begin{array}{l}\text { Penicillium expansum, } \text { P. urticae, } \\
\text { Aspergillus clavatus, Byssochlamys nivea }\end{array}$ & Patulin \\
\hline $\begin{array}{l}\text { Fusarium sporotrichioides, F. graminearum, } \\
\text { F. tricinctum, F. acuminatum }\end{array}$ & Trichothecenes (Deoxynivalenol) \\
\hline $\begin{array}{l}\text { Fusarium moniliforme, F. proliferatum } \\
\text { F. sambucinum, F. napiforme, F. heterosporum, } \\
\text { F. oxysporum, F. solani, F. proliferatum }\end{array}$ & Fusaric acid \\
\hline $\begin{array}{l}\text { Fusarium graminearum, F. culmorum, } \\
\text { F. crookwellense }\end{array}$ & Zearalenone \\
\hline
\end{tabular}

factors, Fusarium spp. may produce trichothecenes, zearalenone (ZEN) and/or fumonisins (Tab. I).

Hay harvested in good conditions has a limited and balanced associated microflora, resulting from the successive superimposition of three ecological types of fungi: field fungi (pre-harvest period), intermediate fungi (during harvest), and storage fungi (storage after harvest). Intermediate and storage fungi are more numerous and diverse in hay harvested and stored in humid conditions [57]. Hygrophilic and heat-tol erant species, such as Aspergillus fumigatus which causes respiratory troubles and could produce gliotoxin, and Stachybotrys atra producing satratoxins $\mathrm{G}$ and $\mathrm{H}$ which causes stachybotryotoxicosis, both predominate in hay harvested and stored in humid conditions. Numerous highly toxinogenic species of Aspergillus and Penicillium have been detected in damp hay and straw $[9,38$, $40,57]$ as well as Fusarium spp. that produce ZEN [82]. As a consequence, a large range of toxins including the harmful PAT, aflatoxins and sterigmatocystin can be found in insufficiently dried hay and straw. 
Making silage in good conditions anaerobiosis and low $\mathrm{pH}$ - usually prevents the development of moulds. The presence of oxygen at the cut edge of the silage or in the silo may favour the growth of micromycetes. However, the addition of large amounts of live yeast as an additive in a silo could be a way to decrease the growth of Paecilomyces spp. and PAT production in grass silage [17]. PAT could be degraded by yeasts and by the producing organism itself [2].

In France, on 34 maize silages tested, $59 \%$ were found to contain PAT and byssochlamic acid [20]. OTA and citrinin may be produced both in maize silage and in dry forages [42, 43, 82]. Penicillium roqueforti is the major contaminant in grass, maize or sugar beet pulp silages in Europe [55]. However the toxins from $P$. roqueforti have a low stability in the silo [50]. Fusarium spp. due to field contamination, can survive in silages and produce some associated toxins [82]. A comparative study on the preservation of lucerne or grass from natural pastures in Italy showed that wrapped balls contain more mycotoxins than hays made with the same forage [87]. Considering such a result and the large use of the wrapped ball technique during the last decade, more research on the risk associated with this type of preservation is imperative.

The spectrum of fungal species present in silage made with maize, sorghum and grass varies with the duration of storage. After two to three months of storage, the species detected still belong to the Penicillium, Fusarium and Aspergillus genera. The Byssochlamys nivea species, which synthesises PAT, appears in silos after about six months of storage [44].

\subsection{Moulds and mycotoxins in feed concentrates}

Cereals are major mycotoxin vectors because they are consumed by both humans and animals [59]. Between 25 and $40 \%$ of cereals world-wide are contaminated with mycotoxins [62]. The most dangerous of these toxins include the aflatoxins produced by Aspergillus flavus and Aspergillus parasiticus. These two fungi are storage moulds often found in cereals, peanuts, cotton and oilseed products from hot and humid countries. They do not affect the plants cultivated in temperate regions, but do affect imported foods. In the European Council Directive 1999/29/CE (22 April 1999) "Substances and products that are undesirable in animal feed", the European Commission set limits of 0.005 ppm for AFB1 in cereals or concentrates.

OTA produced by Penicillium viridicatum may be present in all cereals. It is mainly found in maize, barley, oats, rye and wheat and in oilseed products, particularly if the products were poorly dried before storage (ASPCC, Alimentary Consumption Observatory 1997). The maximum level tolerated in France is $5 \mu \mathrm{g} \cdot \mathrm{kg}^{-1}$ of cereals or concentrates [5]. OTA is synthesised after harvest, this phase being the predominant phase of food contamination.

Trichothecenes, such as DON, diacetoxyscirpenol (DAS), T-2 toxin and hydroxy-T-2 (HT-2) produced by Fusarium spp., may be present in most cereals during harvest and storage. Fusaric acid which is often present in cereals increases the toxicity of trichothecenes through a synergistic mechanism [83]. ZEN is present mainly in maize, and also in smaller amounts in sorghum, sesame seeds, barley, wheat and oats harvested late, and on grains that have suffered damage to the seed coat. Fumonisins (FB1, FB2, FB3) are principally associated with maize and affect wheat less. A study of wheat and maize harvested in France in 1996 and 1997 [73] showed the levels of contamination by fusariotoxins to be variable and to depend on the cereal and the year (Tab. II).

PAT may be produced during the malting of barley. This toxin may have been 
Table II. Natural distribution of Fusarium sp. mycotoxins in France in 1996 and 1997 (adapted from [73]).

\begin{tabular}{|c|c|c|c|c|c|}
\hline \multirow[t]{2}{*}{ Cereal } & \multirow[t]{2}{*}{$\begin{array}{l}\text { No. of } \\
\text { samples }\end{array}$} & \multirow[t]{2}{*}{ Mycotoxins } & \multirow[t]{2}{*}{$\%$ Positive } & \multicolumn{2}{|c|}{$\begin{array}{l}\text { Amount of toxin in positive samples } \\
\qquad\left(\mu \mathrm{g} \cdot \mathrm{kg}^{-1}\right)\end{array}$} \\
\hline & & & & Mean & Range \\
\hline \multirow[t]{3}{*}{ Wheat 1996} & 46 & DON & 40 & 39 & Trace -580 \\
\hline & & NIV & 28 & 24 & Trace -60 \\
\hline & & ZEN & 12 & 9 & Trace -16 \\
\hline \multirow[t]{3}{*}{ Wheat 1997} & 69 & DON & 90 & 87 & Trace -650 \\
\hline & & NIV & 92 & 32 & Trace -232 \\
\hline & & ZEN & 12 & 7 & Trace -9 \\
\hline \multirow[t]{4}{*}{ Maize 1996} & 17 & DON & 84 & 400 & Trace -2800 \\
\hline & & NIV & 78 & 276 & Trace -1300 \\
\hline & & ZEN & 95 & 335 & Trace -1750 \\
\hline & & FB1 & 72 & 370 & Trace -3300 \\
\hline \multirow[t]{4}{*}{ Maize 1997} & 24 & DON & 76 & 100 & Trace -558 \\
\hline & & NIV & 47 & 69 & Trace -250 \\
\hline & & ZEN & 90 & 15 & Trace -40 \\
\hline & & FB1 & 66 & 320 & Trace -1100 \\
\hline
\end{tabular}

involved in the deaths of 100 cows fed dried malt [75].

The oilseed products, grains and cakes currently used in animal feed may also be contaminated by the three genera of moulds, Aspergillus, Fusarium and Penicillium. However, the mycotoxins produced by these moulds are partly destroyed during oil extraction and are further destroyed during industrial processing.

\subsection{Effects of mycotoxins on ruminant health}

Fungal contamination affects both the organoleptic characteristics and the alimentary value of feed, and entails a risk of toxicosis. The biological effects of mycotoxins depend on the ingested amounts, number of occurring toxins, duration of exposure to mycotoxins and animal sensitivity. Also, Mycotoxins can induce health troubles that are specific to each toxin as described below, or affect the immune sta- tus of animals, favouring infections. This is the major reason for the difficulty of diagnosing mycotoxicoses.

The gastrointestinal absorption that controls toxin entry into the blood compartment and their distribution throughout the organism occurs according to three processes: (1) a simple diffusion of polar compounds in the liquid phase, (2) a diffusion in the lipid phase of non-ionic compounds, and (3) an active transport. Lipophilic and low-molecular mass molecules such as aflatoxins and ZEN are candidates for passive transport. The presence of phenolic and carboxylic groups on molecules of OTA, citrinin, cyclopiazonic acid and penicillic acid confers acidic and weakly hydrophilic properties to these molecules. The diffusion of non-ionic forms across the lipid membrane is the principal route of mycotoxin absorption.

Acute aflatoxin poisoning provokes major signs of liver lesions, leading to congestion and bleeding [60,61]. Aflatoxicosis 
causes fatty acid accumulation in the liver, kidneys and heart and may be responsible for encephalopathies and oedemas [59]. The animal may die within a few hours or days. Chronic toxicosis is however more common and, in this case, the liver is also the main target. Aflatoxins act as a DNA intercalating agent by binding to guanine bases and leading to cell death or its transformation into a tumour [74].

Ochratoxicoses has been detected in humans in the Balkans and in pigs in Scandinavian countries. This has rarely been found in ruminants because the micro-organisms of the rumen are able to hydrolyse OTA to produce OTA $\alpha$ which has a lower toxicity. However the detoxification capacity of the rumen may be exceeded in cases of severe poisoning [71]. Acute ochratoxicoses chiefly affects poultry, rats and pigs and is manifested as damage to the kidneys, anorexia and weight loss, vomiting, high rectal temperature, conjunctivitis, dehydration, general weakening and animal death within two weeks after toxin administration [7, 8, 47]. Chronic poisoning induces a decrease in ingestion, polydipsea and kidney lesions. Pigs are particularly sensitive to OTA [18]. Such poisoning has a significant effect for toxin concentrations exceeding $1400 \mu \mathrm{g} \cdot \mathrm{kg}^{-1}$ of feed. OTA has genotoxic properties due to DNA adduct formation [59]. It also has immunotoxic and carcinogenic properties by decreasing the number of natural killer cells responsible for the destruction of tumour cells. Their partial elimination therefore increases the capacity of OTA to induce renal and hepatic carcinomas [46]. OTA also decreases the activity of phosphoenol pyruvate carboxykinase (PEPCK) and reduces the level of renal neoglucogenesis [59]. In addition, OTA inhibits B and T lymphocytes [39].

The main effects of ZEN are reproductive problems and physical changes in genital organs similar to those induced by oestradiol: oedemas and hypertrophy of the genital organs of pre-pubertal females, decreases in the rate of survival of embryos in gestating females, decreases in the amounts of luteinising hormone ( $\mathrm{LH}$ ) and progesterone produced affecting the morphology of uterine tissues, decreases in milk production, feminisation of young males due to decreased testosterone production, infertility and perinatal morbidity. Pigs are the most sensitive animals to ZEN poisoning whereas chickens and cattle show lower sensitivities [12]. ZEN is only produced in very small amounts in natural conditions, and probably in insufficient quantities to cause trouble in ruminants [25]. ZEN has, however, been shown to cause infertility in grazing sheep in New Zealand [88].

Fumonisins mostly affect pigs, poultry and horses, with ruminants seeming to be much less sensitive to this type of contamination. Fumonisins cause deep lesions in the liver, gastrointestinal tract, nervous system and lungs. Acute doses of fumonisins in pigs may inhibit the activity of pulmonary macrophages responsible for the elimination of pathogens, leading to pulmonary oedema. In horses, contamination is manifested as severe neurological lesions leading to locomotive problems and ataxia. Fumonisins inhibit the synthesis of ceramides from sphinganin, blocking the biosynthesis of sphingolipid complexes. The quantity of sphinganins therefore increases and the recycling of sphingosins is blocked, resulting in cell dysfunction followed by cell death [74] (Fig. 1).

PAT has some carcinogenic and mutagenic properties whereas clinical signs of its toxicosis are typical of the nervous syndrome. Animals present hyperaesthesia, lack of coordination of motor organs and paraplegia, possibly resulting in death. The paralysis of gastric reservoirs causes general problems with ingestion and digestion, markedly decreasing milk production and growth. At the molecular level, PAT alters ion permeability and/or intracellular 


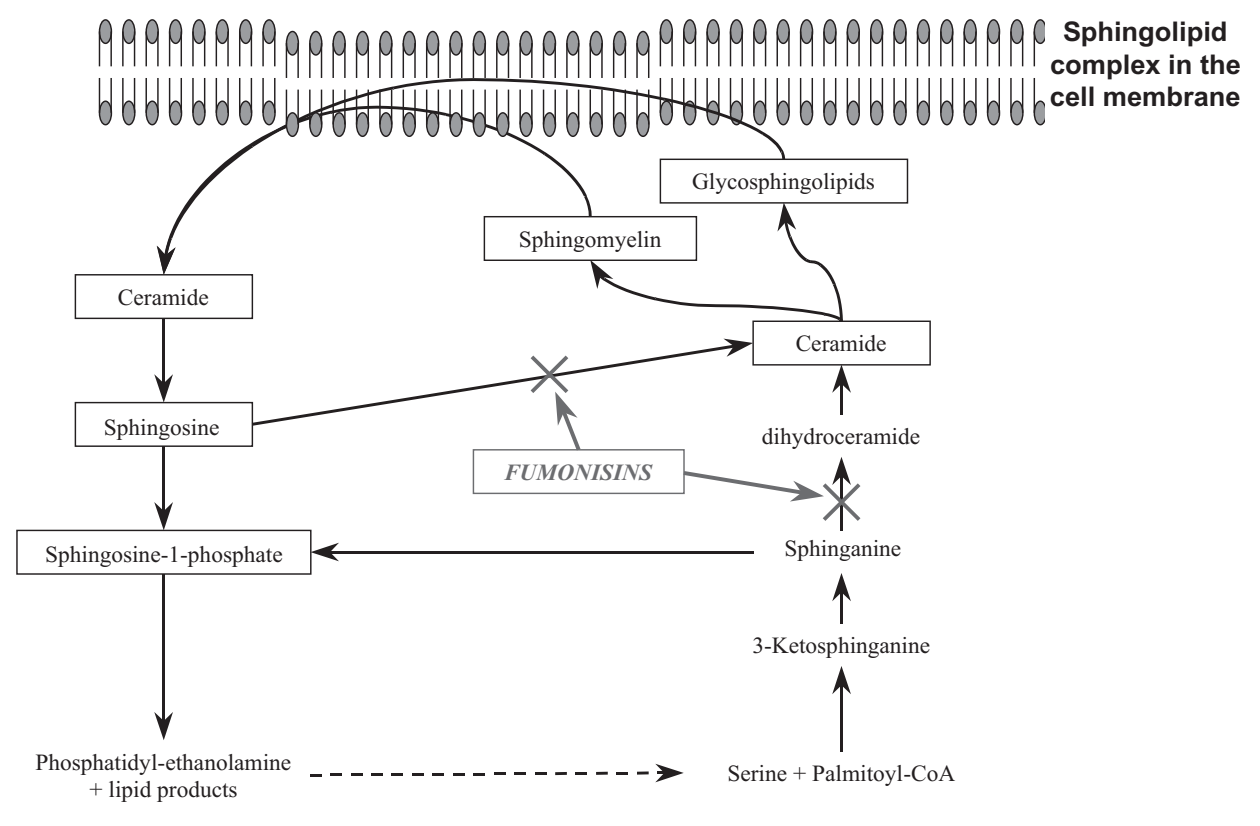

Figure 1. Pathway of de novo synthesis (not in boxes) and turnover of sphingolipids (boxed) in animal cells, and their inhibition by fumonisins. FB1, FB2, FB3 and hydrolysed FB1 inhibit the synthesis of ceramides by specifically binding to sphingosine and sphinganine $\mathrm{N}$-acetyltransferase enzymes, blocking biosynthesis of the sphingolipid complex. This results in the accumulation of sphinganine and the rerouting of the ceramide synthesis pathway to produce sphingosine-1-phosphate from sphinganine. Fumonisins also block reacetylation of the sphingosine released by the turnover of sphingolipids. Following the disruption of sphingolipid metabolism, several bioactive lipid intermediates are created whereas others are lost. Thus, we observe an increase in free intracellular sphingoid bases, which inhibit kinases. There is also an increase in intracellular calcium concentration due to the increase in sphingosine-1-phosphate concentration in the endoplasmic reticulum. In addition, there is an increase in free sphinganine, which affects cellular proliferation and the cell cycle, initiating apoptosis and cellular necrosis. Finally, there is a decrease in the concentration of the sphingolipid complex, which regulates cell growth through cell cycle (adapted from [74]).

communication, causing oxidative stress and cell death [74].

Trichothecenes cause weight loss, vomiting, severe skin problems and bleeding and may, in some cases, be responsible for the death of animals. Like aflatoxins, they have immuno-suppressive properties acting both on the cell immune system and on the number of macrophages, lymphocytes and erythrocytes. T-2 and DON are known to inhibit protein synthesis and cause cell death in various parts of the body.

\subsection{Synergy between mycotoxins}

Feeds are frequently contaminated simultaneously by several moulds which are each able to produce several toxins. There may be synergetic effects between different toxins. For instance, fusaric acid increases 
fumonisin toxicity in the chicken [15], and that of DAS and DON in pigs [83]. A combination of ZEN and fusaric acid increases the concentration in rat milk of each of these compounds by a factor of two to five [65]. An interaction between FB1 and DON increases the amount of blood protein whereas an interaction between FB1 and $\mathrm{T}-2$ toxin leads to an increase in plasma calcium concentration in the chicken [36] or to an increase in haemoglobin and haematocrit concentration in turkeys [35]. Even though body weight is reduced by 18 to $20 \%$ in chickens receiving a feed contaminated with $300 \mathrm{mg}$ FB1 per $\mathrm{kg}$ feed for 20 days after birth, body weight is reduced by $18 \%$ when $5 \mathrm{mg} \mathrm{T}-2$ is added per $\mathrm{kg}$ of feed, by $2 \%$ when $15 \mathrm{mg}$ DON is added per $\mathrm{kg}$, by $32 \%$ when both FB1 and T- 2 are added, and by $19 \%$ when both FB1 and DON are added [36]. In turkeys, in the same conditions, 300 mg FB1 reduced weight gain by 24 to $30 \%$, $4 \mathrm{mg}$ DAS reduced it by $30 \%, 3 \mathrm{mg}$ OTA reduced it by $8 \%$, a combination of FB1 and DAS reduced it by $46 \%$, and a combination of FB1 and OTA reduced it by $37 \%$ [37]. Other combinations, involving DON and DAS, DAS and aflatoxins and aflatoxins and FB1 may also have synergetic effects $[26,27]$.

\section{THE FATE OF MYCOTOXINS IN RUMINANTS}

\subsection{Ruminal metabolism}

Overall, ruminants are more resistant to most mycotoxins than monogastric animals. This suggests that the rumen and its microbial population should play a role in detoxification. The protozoa fraction of the rumen microbial ecosystem seems to be more effective in mycotoxin metabolism than the bacterial fraction, but protozoa are also more sensitive to these toxins [92]. However, bacteria such as Butyrivibrio fibrisolvens, Selenomonas ruminantium and Anaerovibrio lipolytica are able to use $\mathrm{T}-2$ as a source of energy through two enzyme systems [91]. Other strains of $B$. fibrisolvens have been isolated from the rumen and have been shown to be able to degrade derivatives of the toxins DAS, DON, verrucarin $\mathrm{A}, \mathrm{ZEN}$ and OTA in vitro [34, 90, 92].

Toxins T-2, HT-2, DON and DAS are metabolised in the presence of rumen contents when administered at a concentration of $10 \mu \mathrm{g} \cdot \mathrm{mL}^{-1}$ [67]. DAS is deacetylated to produce monoacetoscirpenol (MAS) and scirpenetriol, then de-epoxy MAS and de-epoxyscirpenetriol. T-2 is converted to HT-2 and neosolaniol, each of which is about a tenth as toxic as the parent toxin. The epoxy cycle of DON generates de-epoxy DON, commonly known as DOM-1 which is devoid of any toxicity [10].

OTA is metabolised in the rumen to produce phenylalanine and ochratoxin $\alpha$, which is less toxic than the parent molecule [32]. It may also be esterified to produce ochratoxin C [21] of similar toxicity [8].

ZEN is mostly (more than $90 \%$ ) converted to $\alpha$-zearalenol, which is about ten times more toxic than the parent toxin and to a lesser extent, to $\beta$-zearalenol, which has a low toxicity. Alpha-zearalenol and ZEN can be hydrogenated in the bovine rumen to produce zeranol, an oestrogenic hormone that stimulates animal growth [33].

Aflatoxins are generally poorly degraded in the rumen, with less than $10 \%$ degraded for concentrations from 1.0 to $10.0 \mu \mathrm{g} \cdot \mathrm{mL}^{-1}$ [92]. Formation of aflatoxicol, a highly toxic hydroxylated derivative of AFB1 has also been observed [4]. Many bacteria are completely inhibited by concentrations of AFB1 below $10 \mu \mathrm{g} \cdot \mathrm{mL}^{-1}$. Thus, this toxin may disturb the growth and metabolic activity of rumen micro-organisms.

The major pathways of toxin bioconversion by biological systems are summarised in Table III. The action of the rumen 
Table III. Major routes of mycotoxin bioconversions in biological systems (adapted from [23]).

\begin{tabular}{|c|c|c|c|c|c|c|}
\hline \multirow[t]{2}{*}{ Toxin } & \multicolumn{2}{|c|}{ Oxidation } & \multirow[t]{2}{*}{ Reduction } & \multirow[t]{2}{*}{ Hydrolysis } & \multicolumn{2}{|c|}{ Conjugation } \\
\hline & P450 & Not determined & & & Glucuronide & Other \\
\hline AFB1 & $\begin{array}{l}\text { epoxide } \\
\text { AFM1 } \\
\text { AFP1 } \\
\text { AFQ1 }\end{array}$ & & aflatoxicol & & $\begin{array}{l}\text { AFM1 } \\
\text { AFP1 } \\
\text { AFQ1 }\end{array}$ & epoxide \\
\hline OTA & $\begin{array}{l}4 \mathrm{OH}- \\
\text { OTA }\end{array}$ & & & OTA $\alpha$ & & \\
\hline $\mathrm{T}-2$ & & $\begin{array}{c}\text { 3' OH-T-2 } \\
\text { 3'OH-HT-2 } \\
\text { 3',7diOH-T-2 } \\
\text { 3',7diOH-HT-2 }\end{array}$ & & \begin{tabular}{|c|} 
HT-2 \\
neosolaniol \\
T-2 triol \\
T-2 tetraol \\
de-epoxylated metabolites
\end{tabular} & $\begin{array}{c}\text { HT-2 } \\
\text { neosolaniol }\end{array}$ & \\
\hline DAS & & & & $\begin{array}{c}\text { MAS } \\
\text { scirpenetriol } \\
\text { de-epoxylated metabolites }\end{array}$ & & \\
\hline DON & & & & DOM-1 & & $\begin{array}{c}\text { DON } \\
\text { DOM-1 }\end{array}$ \\
\hline ZEN & & & $\begin{array}{l}\alpha \text {-zearalenol } \\
\beta \text {-zearalenol }\end{array}$ & & $\begin{array}{l}\alpha \text {-zearalenol } \\
\beta \text {-zearalenol }\end{array}$ & \\
\hline FB1 & & & $\begin{array}{l}\text { FB1monoester } \\
\text { FB1 aminopentol }\end{array}$ & & & \\
\hline
\end{tabular}

on toxins may depend on the nature of the diet which may modify the microbial ecosystem and its metabolic activity, but this aspect has not yet been extensively studied. Thus, the capacity to degrade OTA is $20 \%$ lower in animals fed a high proportion of concentrates than in animals fed a forage-based diet $[31,34,96]$. By contrast, other authors found that OTA degradation is accelerated by increasing the content of concentrate in the diet [51].

\subsection{Metabolism in the intestinal epithelium, liver and kidneys}

The intestinal epithelium, liver and kidneys are sites of biotransformation of a large number of compounds. These biotransformations involve two phases of reactions. The first phase comprises reductive, oxidative and hydrolytic reactions. Microsomal cytochromes $\mathrm{P} 450$, mono-oxygenases containing flavin, synthases from prostaglandins, amino-oxidases and alcohol dehydrogenases, are the major enzymes involved in the oxidation reactions, whereas the reduction reactions are controlled by epoxide-hydrolases, aldehyde-reductases or ketone-reductases. In addition, the tissues and body fluids of mammals contain a large number of non-specific esterases and amidases capable of hydrolysing xenobiotic molecules [23]. The second phase comprises conjugating reactions applied on the molecules formed during the first phase. These reactions 


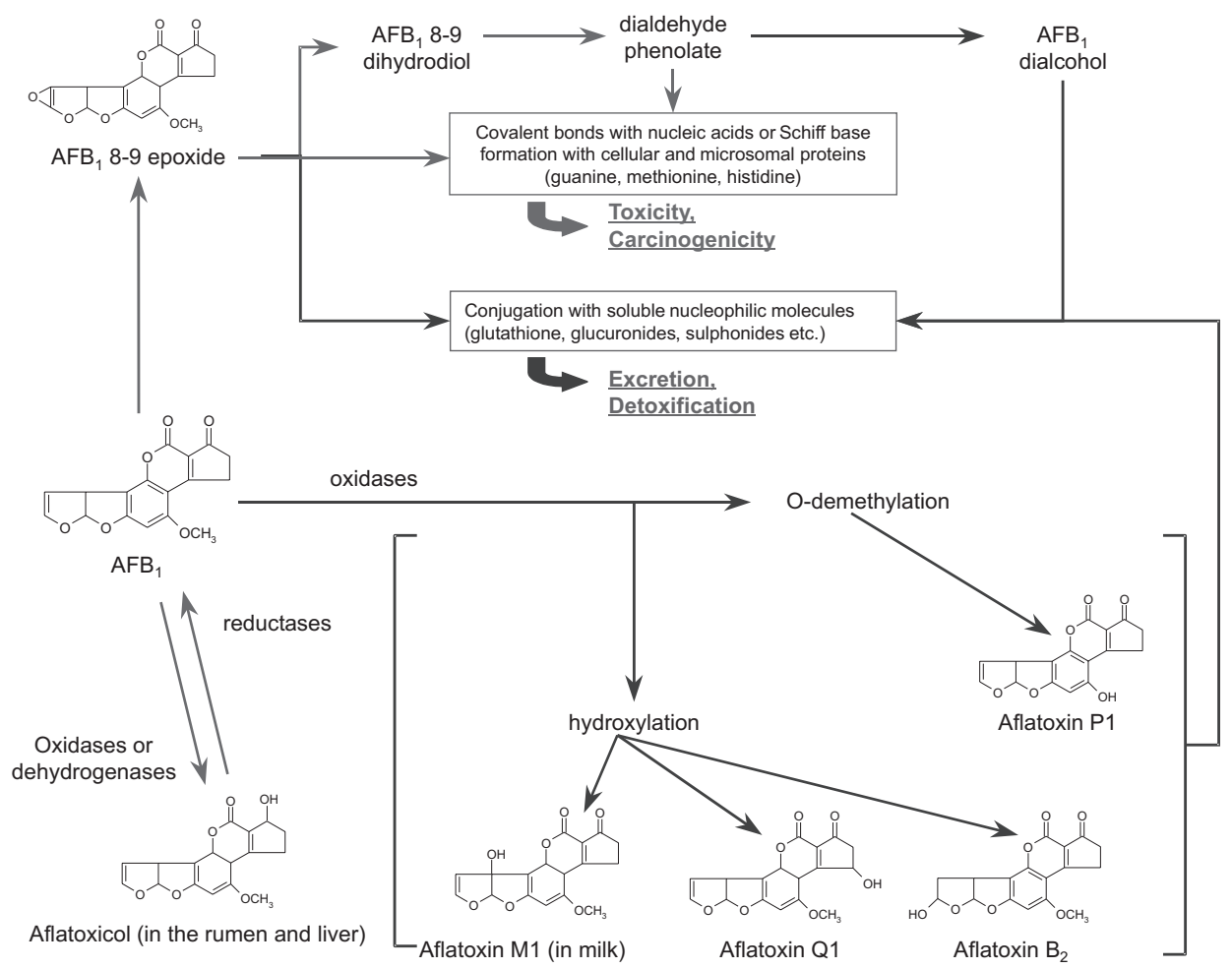

Figure 2. Metabolism of aflatoxin B1 in the liver. Processes of detoxification are shown in black and those leading to toxicity or carcinogenicity are shown in grey (adapted from $[53,86]$ ).

decrease the toxicity and increase the solubility in water of mycotoxins, facilitating their excretion in urine (and milk) and protecting the animal [16]. The major conju gating enzymes are microsomal glucuronosyltransferases, cytosolic sulpho-transferases, methyl-transferases, aminoacyl-transferases, S-glutathione-transferases and N-acetyltransferases [23]. Figure 2 illustrates certain bioconversions of AFB1 in the liver. The epoxidation of AFB1 is an essential step in the acquisition of its mutagenic and carcinogenic characters.

Trichothecenes are mainly detoxified by a glucuronidation reaction and by the reduction of the epoxy group responsible for the reactivity of these metabolites. The liver microsomal cytochrome P450 converts OTA to hydroxy-ochratoxins A (OH-OTA), which have immuno-suppressive properties identical to those of OTA [13]. The half-life of T-2 in plasma is less than 20 minutes. T-2 is rapidly metabolised in two steps. In the first step, T-2 is de-acetylated to give HT-2 and a smaller amount of T-2-triol. These metabolites are then conjugated with glucuronic acid, facilitating their excretion in bile. Two other hydroxylated metabolites are also produced: OH-HT-2 and diOH-HT-2. Compounds such as de-epoxy T-2 or de-epoxy T-2-triol may also be formed. DAS is metabolised to 
de-epoxylated and de-acetylated products. DON is converted to de-epoxy DON (or DOM-1), which is in turn subjected to glucuronidation, rendering this molecule more hydrophilic and increasing its excretion from the animal's body [10].

FB1 and DON are eliminated in bile and are absorbed in small amounts within the digestive tract. They mostly end up in the faeces ( $61 \%$ of FB1 and 54 to $75 \%$ of DON) and as trace contaminants in the urine (1 to $3 \%$ ). Liver hydrolases or intestinal enzymes may partially hydrolyse FB1 to produce a monoester and aminopentol, both of which are themselves excreted in the faeces [23].

ZEN is subjected to the action of liver ketone-reductases, resulting in the production of $\alpha$ - and $\beta$-zearalenol. Genetic differences between species may account for differences in the sensitivity of animals to ZEN [23].

\section{ROUTES OF MYCOTOXIN ELIMINATION}

\subsection{Urinary and faecal excretion}

As discussed before, ruminal and hepatic bioconversions of mycotoxins alter the polarity of toxins and consequently, their affinity to water or lipids respectively. Their absorption through the digestive tract and their excretion in either the urine, faeces or milk, is therefore under the control of tissue or digestive microbial biotransformations in ruminants. Following oral administration, urinary excretion is most efficient for mycotoxins which are strongly absorbed and metabolised, such as AFB1, citrinin, OTA, PAT and ZEN.

Faecal excretion results from a lack of absorption by the gastrointestinal tract or a highly efficient elimination of toxins or their metabolites by the biliary system. DON, FB1 and T-2 are poorly absorbed by the gastrointestinal tract, whereas AFB1, cyclopiazonic acid, OTA and ZEN are eliminated in significant amounts as conjugated metabolites in bile [22].

\section{2 . Excretion in milk}

The excretion of toxins and their metabolites in milk represents another route by which these compounds may be eliminated from the animal. This process may involve intercellular filtration, passive diffusion across membranes or active transport via secretion vesicles. AFB1, OTA, ZEN and their metabolites, particularly AFM1, can represent a potential risk to the consumer due to their carryover in cow's milk (Tab. IV). AFM1 was found at the maximum concentration in milk two days after ingestion of AFB1 by dairy cows [95]. The same authors also indicated that AFM1 disappeared 4 days after AFB1 was removed from the diet. This means that the mechanisms involved in the mycotoxin transfer do not need adaptation.

The rate of transfer of aflatoxins from feeds to milk is low, 0.3 to $2.2 \%$ [84]. In Europe, the AFM1 content in milk must not exceed the maximum authorised concentration of $50 \mathrm{ng} \cdot \mathrm{L}^{-1}$. DON has not been detected in milk, even if it may be present in very large amounts in feed. A single dose of $920 \mathrm{mg}$ of DON, administered to cows, led to a concentration of free and conjugated DON of only $4 \mu \mathrm{g} \cdot \mathrm{L}^{-1}$ in milk [66]. Radioactively labelled DON fed to lactating ewes is rapidly and almost exclusively detected in urine, with only trace amounts of metabolites detected in milk [68]. The rate of carryover of T- 2 is between 0.05 and $2 \%$. OTA and its metabolites are detected in cow's milk only if the toxin is administered in quantities reaching $1.66 \mathrm{mg}$ OTA per $\mathrm{kg}$ body weight [68]. The lethal single oral dose in cattle is high, more than $13 \mathrm{mg}$ per $\mathrm{kg}$ body weight. Goats seem to be more sensitive since they are dramatically affected by $3 \mathrm{mg}$ per $\mathrm{kg}$ body weight. For FB1, only Hammer et al. (1996), as cited by [84], were 
Table IV. Mycotoxin residues in milk of cows given contaminated feed or oral doses of toxins. Doses are expressed in $\mathrm{mg} \cdot \mathrm{kg}^{-1}$ body weight, in concentration in the diet (ppm), or in $\mathrm{mg}$ or $\mathrm{g}$ for daily oral doses (adapted from [22]).

\begin{tabular}{lcccc}
\hline Mycotoxin & Dose & $\begin{array}{c}\text { Duration of } \\
\text { exposure (days) }\end{array}$ & Forms excreted in milk & $\begin{array}{c}\text { Concentration in milk } \\
(\mathrm{ppb})\end{array}$ \\
\hline AFB1 & $0.35 \mathrm{mg} \cdot \mathrm{kg}^{-1}$ & 3 & AFM1 & 0.10 \\
DON & $1.8 \mathrm{mg} \cdot \mathrm{kg}^{-1}$ & 1 & DON & $<4$ \\
& $66 \mathrm{ppm}$ & 5 & DOM-1 & 30 \\
& $880 \mathrm{ppm}$ & 3 & DOM-1 conjugate & 220 \\
FB1 & $3 \mathrm{mg} \cdot \mathrm{kg}^{-1}$ & 14 & FB1 & 0 \\
OTA & $50 \mathrm{mg}$ & 4 & OTA $\alpha$ & 150 \\
& $1 \mathrm{~g}$ & 4 & OTA & 100 \\
& & & OTA $\alpha$ & 700 \\
T-2 & $50 \mathrm{ppm}$ & 15 & T-2 & $10-160$ \\
ZEN & $25 \mathrm{ppm}$ & 7 & ZEN & 481 \\
& & & $\alpha$-zearalenol & 508 \\
ZEN & $40 \mathrm{ppm}$ & 21 & -zearalenol & 370 \\
ZEN & $1.8 \mathrm{~g}$ and $6 \mathrm{~g}$ & 1 & ZEN & 2.5 \\
& & & $\alpha$-zearalenol & 3.0 \\
& & & ZEN & 4.0 and 6.1 \\
& & & $\alpha$-zearalenol & 1.5 and 4.0 \\
& & & $\beta$-zearalenol & 4.1 and 6.6 \\
\hline
\end{tabular}

able to estimate an average carryover rate of $0.05 \%$ for a single administration of $3 \mathrm{mg}$ of toxin per $\mathrm{kg}$ of feed. Twenty-four hours later, FB1 was no longer present in the milk. In other studies, FB1 could not be detected in milk [72, 79]. A daily ingestion of $544.5 \mathrm{mg}$ of ZEN for 21 days leads to the presence of the original toxin and of $\alpha$-zearalenol in cow's milk, with a cumulative transfer of $0.06 \%$ of the dose. The rate of transfer is highly dependent on the dose administered; it falls to $0.016 \%$ and $0.008 \%$ following the administration of single doses of $1.8 \mathrm{~g}$ and $6 \mathrm{~g}$ of $\mathrm{ZEN}$ respectively [69]. In this case, the presence of $\beta$ zearalenol was shown in addition to the other two compounds. The rate of carryover of this toxin into milk is therefore low and presents no real risk to consumers of dairy products.

\section{EFFECTS OF MYCOTOXINS ON FEED INTAKE AND PERFORMANCE OF DAIRY COWS}

The contamination of feeds by moulds or mycotoxins generally leads to a decrease in the amount of feed intake. Although it is difficult to separate the repulsive effects of these contaminants from the digestive and metabolic disorders caused by toxins, ruminants seem to be less sensitive than monogastric animals. The presence of AFB1 at a concentration of $600 \mu \mathrm{g} \cdot \mathrm{kg}^{-1}$ of concentrate has been shown to significantly decrease the amount of feed intake by fattening cows whereas concentrations of 60 to $300 \mu \mathrm{g} \cdot \mathrm{kg}^{-1}$ had no effect $[28,29,30]$. The contamination of feed by $13 \mathrm{mg}$ of pure AFB1 per day had no effect on ingestion 
whereas an identical dose of a mixture of aflatoxins significantly reduced feed intake [3]. A decrease in this parameter is generally associated with a lower milk production and sometimes changes in milk composition. A rapid decrease in production and an increase in the lipid content of milk following the administration of 50 to $150 \mathrm{mg}$ of AFB1 have also been observed [48].

Conflicting results have been obtained regarding the effects of trichothecenes on feed intake and milk production in cows. As an example, a decrease in intake and milk production was observed following the administration of 6 to $8 \mathrm{mg}$ DON per $\mathrm{kg}$ of concentrate $[89,93]$ whereas no decrease in these two factors was shown after the administration of up to $12 \mathrm{mg}$ DON per $\mathrm{kg}$ of concentrate $[6,10]$. FB1 seems to only have an effect on daily food consumption since the addition of $148 \mathrm{mg}$ of this toxin per $\mathrm{kg}$ of feed had no effect on weaned calves [56]. Only the rate of ingestion was observed to have decreased.

A decrease in milk production results from the contamination of the cereal fraction in the diet containing ZEN [49]. On the contrary, no effect on milk production was demonstrated after the administration of ZEN at concentrations from 385 to $1982 \mu \mathrm{g}$ per $\mathrm{kg}$ of feed, for seven days [81].

Such inconsistent results can be explained by the uncontrolled presence of other toxins in feed and their potential synergy. Also, as indicated before, the detoxification process in the rumen is dietarydependant.

\section{REDUCTION OF MYCOTOXICO- LOGICAL RISKS IN RUMINANTS}

\subsection{Control of mould development in plants}

The control of mould growth involves maintaining the physical integrity of cereal grains with the aim of limiting the access of moulds to nutrients present in the grains, and the strict control of environmental conditions such as water content, oxygen concentration and temperature. Drying is thus an essential step in the preservation process of dry feed, and anaerobiosis is a prerequisite to the storage of feed in a moist form. The use of antifungal agents may provide additional guarantees if there is a predictable risk. Propionic acid inhibits the development of moulds by lowering $\mathrm{pH}$ and reducing ATP formation via the electron transfer pathway. Sodium chloride acts on the osmotic pressure of cells and decreases the free-water content $\left(\mathrm{a}_{\mathrm{w}}\right)$ of insufficiently dried hay. Ammonia destroys the entire mycoflora, but its effect is only transient [57]. It is also possible to control mould contamination by using plant varieties selected for resistance to fungal contamination. Plant breeders are now working in this direction.

\subsection{Treatments limiting the effects of mycotoxins}

\subsubsection{Physical methods}

Methods such as grain cleaning by washing with water or sodium carbonate to reduce the contamination of maize with Fusarium toxins, manually sorting out contaminated grains by the physical aspect of grains or by fluorescence to detect the presence of some mycotoxins, have been used. Other toxin inactivating techniques have been proposed like high temperature, UV, $\mathrm{X}$-rays or microwave irradiation, and solvent extraction of toxins [80]. Dilution of contaminated feed with safe feed is also in current use.

The addition of binding agents able to fix mycotoxins may reduce the bioavailability of these compounds in animals and limit the risks associated with the presence of residues in animal products destined for human consumption. In the case of AFB1, hydrated sodium calcium aluminosilicates (HSCAS) 
and phyllosilicates derived from natural zeolites have a high affinity, both in vitro and in vivo. However, many studies have shown these compounds to be unable to adsorb other mycotoxins. Zeolites, which are hydrated aluminosilicates of alkaline cations, are able to fix AFB1 and ZEN [63, 64]. Bentonites have a lamellar crystalline microstructure, the composition and adsorption properties of which depend on the interchangeability of the cations positioned in the various layers. Bentonites have been shown to be effective for the adsorption of AFB1 and T-2, but not for the adsorption of ZEN or nivalenol [70]. Other clays, such as kaolin, sepiolite and montmorillonite, bind AFB1 but less efficiently than HSCAS and bentonites.

Activated carbon is obtained by pyrolysis and the activation of organic compounds. It has a more heterogeneous porous structure. Activated carbon is also able to bind mycotoxins [24]. Resins such as cholestyramine and polyvinylpolypyrrolidoxynivalenol are also able to bind OTA and AFB1 [64]. These binders may have adverse nutritional effects. The large amounts that must be added to get a perceptible effect may also reduce the bioavailability of certain minerals or vitamins in the diet. Some of these binders are not biodegradable and may affect the efficacy of retention basins and digesters used for the treatment of animal effluents. Clays render wet floors slippery, increasing the risk of accidents for both animals and human staff. They also present a risk of contamination by heavy metals and dioxin [14].

\subsubsection{Chemical methods}

A variety of chemical agents such as acids, bases (ammonia, caustic soda), oxidants (hydrogen peroxide, ozone), reducing agents (bisulphites), chlorinated agents and formaldehyde, have been used to degrade mycotoxins in contaminated feeds, particularly aflatoxins [80]. However, these techniques are not totally efficient and are expensive and not well considered by consumers.

\subsubsection{Microbiological methods}

Certain strains of lactic acid bacteria, propionibacteria and bifidobacteria have cell wall structures that can bind mycotoxins $[1,19,97]$ and limit their bioavailability in the animal body. Mycotoxins are then eliminated in the faeces without significant detrimental effects on the animals or any risk for toxic residues to be found in edible animal products. Research is currently underway to develop new classes of natural organic mycotoxin binders. Glucomannans extracted from the external part of the cell wall of the yeast Saccharomyces cerevisiae are able to bind certain mycotoxins (Tab. V). Their great binding capacity results from the large area available for exchange. Thus, $500 \mathrm{~g}$ of glucomannans from yeast cell-wall have the same adsorption capacity as $8 \mathrm{~kg}$ of clay [14]. This binder reduces the AFM 1 content of milk by $58 \%$ in cows given a diet contaminated with aflatoxin $\mathrm{B} 1$ at a concentration of $0.05 \%$ of dry matter [94].

Certain micro-organisms are also able to metabolise mycotoxins (Corynebacterium rubrum) in contaminated feed or to biotransform them (Rhizopius, Aspergillus, Eurotium) [52]. However, these biological

Table V. Capacity of glucomannans from Saccharomyces cerevisiae to bind to mycotoxins (adapted from [14]).

\begin{tabular}{lc}
\hline Mycotoxins & \% Binding \\
\hline Aflatoxins (total) & 95.0 \\
Fumonisins & 67.0 \\
ZEN & 77.0 \\
T-2 & 33.4 \\
Citrinin & 18.4 \\
DAS & 12.7 \\
DON & 12.6 \\
OTA & 12.5 \\
NIV & 8.2 \\
Fusariotoxin & 7.9 \\
\hline
\end{tabular}


processes are generally slow and have a low efficiency. A new approach has been proposed, involving the isolation of Aspergillus flavus and $A$. parasiticus strains that do not produce aflatoxins, using them to out-compete natural toxin-producing strains [11]. These strains occupy the same ecological niche as toxin-producing strains, so they decrease the level of contamination with toxin-producing moulds.

\section{CONCLUSION}

Many studies have been carried out in the last twenty years to investigate the biological implications of the presence of mycotoxins in human and animal foods. The teratogenicity, carcinogenicity and general toxicity of these molecules constitute a risk to animal and human health. This risk is currently difficult to evaluate. In the light of the growing interest of consumers in food safety, the animal and human food industries and farmers must be alerted to possible mycotoxicological risks.

The development of physical, chemical and biotechnological tools to improve seed production, cultivation, harvest and storage of forages and cereals, is essential to reduce the level of contamination of foods and feeds. However, the total elimination of moulds and their toxins must be considered as impossible. For this reason, there is a need for additional current preventive measures with the use of agents that are able to bind toxins, thus limiting their bioavailability in animals (and perhaps also in humans). Research is currently undertaken to investigate the mechanisms by which natural binders interact with toxins. This research should lead to the development of new products that are more efficient on a larger range of mycotoxins without limiting the bioavailability of nutrients and micronutrients in animals. The application of such products to human food could also be considered in geographical zones at risk in the world.
It is reassuring that ruminants seem to act as an effective "filter" against these toxins which contaminate much of the plant world and are found as residues in other animal species. The rumen and its microbial population account for the efficacy of toxin bioconversion and elimination in ruminants.

\section{ACKNOWLEDGEMENTS}

The authors would particularly like to thank Gérard Bertin and Georges Jeminet for their personal involvement in the setting up and carrying out their research on biological binders. They would also like to thank the INRA institute and Alltech company for funding their research.

\section{REFERENCES}

[1] Ahokas J., El-Nemazi H., Kankaanpää P., Mykkänen H., Salinen S., A pilot clinical study examining the ability of a mixture of Lactobacillus and Propionibacterium to remove aflatoxin from the gastrointestinal tract of healthy Egyptian volunteers, Rev. Méd. Vét. 149 (1998) 568.

[2] Anderson M.S., Dutton M.F., Harding K., Production and degradation of patulin by Paecilomyces species, a common contaminant of silage, J. Sci. Food Agric. 30 (1979) 229-237.

[3] Applebaum R.S., Brackett R.E., Wiseman D.W., Marth E.H., Responses of dairy cows to dietary aflatoxin: feed intake and yield, toxin content, and quality of milk of cows treated with pure and impure aflatoxin, J. Dairy Sci. 65 (1982) 1503-1508.

[4] Auerbach H., Maas R.F.M., Op Den Camp H.J.M., Pol A., Fink-Gremmels J., Biodegradation of aflatoxin B1 by bovine rumen microorganisms in vitro and its effects on rumen fermentation, Rev. Méd. Vét. 149 (1998) 573.

[5] Boutrif E., Canet C., Mycotoxin prevention and control: FAO programmes, Rev. Méd. Vét. 149 (1998) 681-694.

[6] Charmley E., Trenholm H.L., Thompson B.K., Vudathala D., Nicholson J.W.G., Prelusky D.B., Charmeley L.L., Influence of level of deoxynivalenol in the diet of dairy cows on feed intake, milk production, and its composition, J. Dairy Sci. 76 (1993) 3580-3587.

[7] Chu F.S., Noh I., Chang C.C., Structural requirements for ochratoxin intoxication, Life Sci. 11 (1972) 503. 
[8] Chu F.S., Studies in ochratoxin, CRC Crit. Rev. Toxicol. 2 (1974) 499.

[9] Clevstroem G., Göransson B., Hlödversson R., Pettersson H., Aflatoxin formation in hay treated with formic acid and in isolated strains of Aspergillus flavus, J. Stored Prod. Res. 17 (1981) 151-161.

[10] Côté L.-M., Dalhem A.M., Yoshizawa T., Swanson S.P., Buck W.B., Excretion of deoxynivalenol and its metabolite in milk, urine, and feces of lactating dairy cows, J. Dairy Sci. 69 (1986) 2416-2423.

[11] Cotty P.J., Bhatnagar D., Variability among atoxigenic Aspergillus flavus strains to prevent aflatoxin contamination and production of aflatoxin biosynthetic pathway enzymes, Appl. Environ. Microbiol. 60 (1994) 2248-2251.

[12] Coulombe R.A. Jr., Symposium: Biological action of mycotoxins, J. Dairy Sci. 76 (1993) 880-891.

[13] Creppy E.E., Störmer F.C., Roschenthamler R., Dirheimer G., Effects of two metabolites of ochratoxin A, (4R)-4-hydroxyochratoxin A and ochratoxin $\alpha$, on immune response in mice, Inf. Immun. 39 (1983) 1015.

[14] Devegowda G., Mettre les mycotoxines sur la touche: d'où viennent les glucomannanes estérifiés, Feed. Times 4 (2000) 12-14.

[15] D’Mello J.P.F., MacDonald A.M.C., Mycotoxins, Anim. Feed Sci. Technol. 69 (1997) 155-166.

[16] Dominguez-Bello M.G., Detoxification in the rumen, Ann. Zootech. 45 (Suppl.) (1996) 323327.

[17] Dutton M.F., Westlake K., Anderson M.S., The interaction between additives, yeasts and patulin production in silage, Mycopathologia 87 (1984) 29-33.

[18] Elling F., Moller T., Mycotoxin nephropathy in pigs, Bull. World Health Org. 49 (1973) 411.

[19] El-Nemazi H., Kankaanpää P., Salinen S., Mykkänen H., Ahokas J., Use of probiotic bacteria to reduce aflatoxin uptake, Rev. Méd. Vét. 149 (1998) 570.

[20] Escoula L., Moisissures des ensilages et conséquences toxicologiques, Fourrages 69 (1977) 97-114.

[21] Galtier P., Alvinerie M., In vitro transformation of ochratoxin A by animal microbial floras, Ann. Rech. Vét. 7 (1976) 91-98.

[22] Galtier P., Biological fate of mycotoxins in animals, Rev. Méd. Vét. 149 (1998) 549-554.

[23] Galtier P., Biotransformation and fate of mycotoxins, J. Toxicol.-Toxin Rev. 18 (1999) 295-312.

[24] Galvano F., Galofaro V., Galvano G., Occurrence and stability of aflatoxin M1 in milk and milk products: a worldwide review, J. Food Prot. 59 (1996) 1079-1090.

[25] Guerre P., Bailly J.-D., Bénard G., Burgat V., Excrétion lactée des mycotoxines : quels risques pour les consommateurs ?, Rev. Méd. Vét. 151 (2000) 7-22.

[26] Harvey R.B., Edrington T.S., Kubena L.F., Elissable M.H., Rottinghaus G.E., Influence of aflatoxin and fumonisin B1 - containing culture material on growing barrows, Am. J. Vet. Res. 56 (1995) 1668-1672.

[27] Harvey R.B., Edrington T.S., Kubena L.F., Elissable M.H., Corrier D.E., Rottinghaus G.E., Effect of aflatoxin and diacetoxyscirpenol in ewe lambs, Bull. Environ. Contam. Toxicol. 54 (1995) 325-330.

[28] Helferich W.G., Aflatoxin in food-producing animals: metabolism and transmission, Dissert. Abstr. Int. B 44 (1984) 3583.

[29] Helferich W.G., Baldwin R.L., Hsieh D.P.H., $\left[{ }^{14} \mathrm{C}\right]$-aflatoxin B1 metabolism in lactating goats and rats, J. Anim. Sci. 62 (1986) 697-705.

[30] Helferich W.G., Garret W.N., Hsieh D.P.H., Baldwin R.L., Feedlot performance and tissue residues of cattle consuming diets containing aflatoxins, J. Anim. Sci. 62 (1986) 691-696.

[31] Hohler D., Sudekum K.H., Wolffram S., Frohlich A.A., Marquardt R.R., Metabolism and excretion of ochratoxin A fed to sheep, J. Anim. Sci. 77 (1999) 1217-1223.

[32] Hult K., Teiling A., Getenbeck S., Degradation of ochratoxin A by a ruminant, Appl. Environ. Microbiol. 32 (1976) 443-444.

[33] Kennedy D.G., Hewitt S.A., McEvoy J.D., Currie J.W., Cannavan A., Blanchflower W.J., Elliot C.T., Zeranol is formed from Fusarium sp. toxins in cattle in vivo, Food Addit. Contam. 15 (1998) 393-400.

[34] Kiessling K.-H., Pettersson H., Sandholm K., Olsen M., Metabolism of aflatoxin, ochratoxin, zearalenone, and three trichothecenes by intact rumen fluid, rumen protozoa, and rumen bacteria, Appl. Environ. Microbiol. 47 (1984) 1070-1073.

[35] Kubena L.F., Edrington T.S., Kamps-Holtzapple C., Harvey R.B., Elissalde M.H., Rottinghaus G.E., Influence of fumonisin B1 present in Fusarium moniliforme culture material and T-2 toxin on turkey poults, Poult. Sci. 74 (1995) 306-313.

[36] Kubena L.F., Edrington T.S., Harvey R.B., Buckley S.A., Phillips T.D., Rottinghaus G.E., Casper H.H., Individual and combined effects of fumonisin B1 present in Fusarium moniliforme culture material and T-2 toxin or deoxynivalenol in broiler chicks, Poult. Sci. 76 (1997) 1239-1247.

[37] Kubena L.F., Edrington T.S., Harvey R.B., Phillips T.D., Sarr A.B., Rottinghaus G.E., Individual and combined effects of fumonisin B1 present in Fusarium moniliforme culture material and diacetoxyscirpenol or ochratoxin A in turkey poults, Poult. Sci. 76 (1997) 256-264. 
[38] Lacey J., Potential hazards to animals and man from microorganisms in fodders and grains, Trans. Br. Mycolog. Soc. 65 (1975) 171.

[39] Lea T., Steien K., Stormer F.C., Mechanism of ochratoxin A induced immunosuppression, Mycopathologia 107 (1989) 153.

[40] Le Bars J., Mycoflore des fourrages secs : croissance et développement des espèces selon les conditions hydrothermiques de conservation, Rev. Mycol. 40 (1976) 347-60.

[41] Le Bars J., Facteurs de l'accumulation d'acide pénicillique dans les denrées d'origine végétale, Sci. Alim. 2 HS II (1982) 29-33.

[42] Le Bars J., Escoula J., Mycoflore des fourrages secs. I - Inventaire et fréquence des espèces, Ann. Rech. Vét. 4 (1973) 273-282.

[43] Le Bars J., Escoula J., Champignons toxinogènes des fourrages secs et ensilés, Bull. Off. Int. Epiz. 79 (1973) 1213-1246.

[44] Le Bars J., Escoula G., Champignons contaminant les fourrages. Aspects toxicologiques, Aliment. Vie 62 (1974) 125-142.

[45] Le Bars J., Le Bars P., Recent acute and subacute mycotoxicoses recognized in France, Vet. Res. 27 (1996) 383-394.

[46] Luster M.I., Germolec D.R., Burleson G.R., Jameson C.W., Ackermann M.F., Lamm K.R., Hayes H.T., Selective immunosuppression in mice of natural killer cell activity by ochratoxin A, Cancer Res. 47 (1987) 2259.

[47] Marquardt R.R., Frohlish A.A., A review of recent advances in understanding ochratoxicosis, J. Anim. Sci. 70 (1992) 3968-3988.

[48] Mertens D.R., Watt R.D., Acute aflatoxicosis in lactating dairy cows, J. Dairy Sci. 60 (Suppl. 1) (1977) 153-154.

[49] Mirocha C.J., Schauerhamer B., Pathre S.V., Isolation, detection, and quantification of zearalenone in maize and barley, J. Assoc. Off. Appl. Chem. 57 (1974) 1104-1109.

[50] Muller H.M., Amend R., Formation and disappearance of mycophenolic acid, patulin, penicillic acid and PR toxin in maize silage inoculated with Penicillium roquefortii, Arch. Anim. Nutr. 50 (1997) 213-225.

[51] Muller H.M., Lerch C., Muller K., Eggert W., Kinetic profiles of ochratoxin A and ochratoxin alpha during in vitro incubation in buffered forestomach and abomasal contents from cows, Nat. Toxins 6 (1998) 251-258.

[52] Nakazato M., Morozumi S., Saito K., Fujinuma K., Nishima T., Kasai N., Interconversion of aflatoxin B1 and aflatoxicol by several fungi, Appl. Environ. Microbiol. 56 (1990) 14651470.

[53] Neal G.E., Participation of animal biotransformation in mycotoxin toxicity, Rev. Méd. Vét. 149 (1998) 555-560.
[54] Nelson C.E., Strategies of mold control in dairy feeds, J. Dairy Sci. 76 (1993) 898-902.

[55] Nout M.J.R., Bouwmeester H.M., Haaksma J., Dijk H. van, Fungal growth in silages of sugarbeet press pulp and maize, J. Agric. Sci. 121 (1993) 323-326

[56] Osweiler G.D., Kehrli M.E., Stabel J.R., Thurston J.R., Ross P.F., Wilson T.M., Effects of fumonisin-contaminated corn screenings on growth and health of feeder calves, J. Anim. Sci. 71 (1993) 459-466.

[57] Pelhate J., La microbiologie des foins, in: Demarquilly C. (Ed.), les fourrages secs: récolte, traitement, utilisation, INRA Editions, Paris, 1987, pp. 63-81.

[58] Pfohl-Leszkowicz A., Écologie des moisissures et des mycotoxines. Situation en France, Cah. Nutr. Diét. 35 (2000) 379-388.

[59] Pfohl-Leszkowicz A., Risques mycotoxicologiques pour la santé des animaux et de l'homme, Cah. Nutr. Diét. 35 (2000) 389-397.

[60] Pier A.C., Major biological consequences of aflatoxicosis in animal production, J. Anim. Sci. 7012 (1992) 3964-3967

[61] Pier A.C., Richard J.L., Mycoses and mycotoxicoses of animals caused by aspergilli, Biotechnology 23 (1992) 233-248.

[62] Pittet A., Natural occurrence of mycotoxins in foods and feeds - an update review, Rev. Méd. Vét. 149 (1998) 479-492.

[63] Piva G., Galvano F., Pietri A., Piva A., Detoxification methods of aflatoxins, Ann. Rev. Nutr. Res. 15 (1995) 767-776.

[64] Piva A., Galvano F., Managing mycotoxin impact: Nutritional approaches to reduce the impact of mycotoxins, in: Lyons T.P., Jacques K.A. (Eds.), Proceeding of Alltech's 15th Annual Symposium, Nottingham University Press, Nottingham, UK, 1999, pp. 381-399.

[65] Porter J.K., Wray E.M., Rimando A.M., Stancel P.C., Bacon C.W., Voss K.A., Lactational passage of fusaric acid from the feed of nursing dams to the neonate rat and effects on pineal neurochemistry in the F1 and F2 generations at weaning, J. Toxicol. Environ. Health 49 (1996) 161-175.

[66] Prelusky D.B., Trenholm H.L., Lawrence G.A., Scott P.M., Nontransmission of deoxinyvalenol (vomitoxin) to milk following oral administation to dairy cows, J. Environ. Sci. Health B 19 (1984) 593-609.

[67] Prelusky D.B., Veira D.M., Trenholm H.L., Hartin K.E., Excretion profiles of the mycotoxin deoxynivalenol, following oral and intravenous administration to sheep, Fund. Appl. Toxicol. 6 (1986) 356.

[68] Prelusky D.B., Veira D.M., Trenholm H.L., Foster B.C., Metabolic fate and elimination in milk, urine and bile of deoxynivalenol following administration to lactating sheep, J. Environ. Sci. Health B 22 (1987) 125-148. 
[69] Prelusky D.B., Scott P.M., Trenholm H.L., Lawrence G.A., Minimal transmission of zearalenone to milk of dairy cows, J. Environ. Sci. Health B 25 (1990) 87-103.

[70] Ramos A.J., Fink-Gremmels J., Hernandez E., Prevention of toxic effect of mycotoxins by means of non-nutritive adsorbent compounds, J. Food Prot. 59 (1996) 631-641.

[71] Ribelin W.E., Fukushima K., Still P.E., The toxicity of ochratoxin A to ruminants, Can. J. Comp. Med. 42 (1978) 172-176.

[72] Richard J.L., Meerding G., Maragos C.M., Tumbleson M., Bordson G., Rice L.G., Ross P.F., Absence of detectable fumonisins in the milk of cows fed with Fusarium proliferatum (Matsushima) Nirenberg culture material, Mycopathologia 133 (1996) 123-126.

[73] Richard-Molard D., Mycotoxin occurrence, identification of Fusarium species and role of processing, IRTAC Conference, 1st-2nd December 1999, Paris, France, (internal document: IRTAC, 16 rue Nicolas Fortin, 75013 Paris), 1999.

[74] Riley R.T., Mechanistic interactions of mycotoxins: theoretical considerations, in: Sinha K.K., Bhatnagar D. (Eds.), Mycotoxins in Agriculture and Food Safety, Marcel Dekker Inc., 1998, pp. 227-253.

[75] Rodricks J.V., Hesseltine C.W., Melhmann M.A., Mycotoxins in Human Health, Pathotox. Publishers Inc, Part Forest South, IL, USA, 1977.

[76] Schoental R., Mycotoxins and the Bible, Perspect. Biol. Med. 28 (1984) 117-120.

[77] Schoental R., Mycotoxins, porphyrias and the decline of the Etruscans, J. Appl. Toxicol. 11 (1991) 453-454.

[78] Schoental R., Mycotoxins in food and the plague in Athens, J. Nutr. Med. 4 (1994) 83-85.

[79] Scott P.M., Delgado T., Prelusky D.B., Trenholm H.L., Miller J.D., Determination of fumonisins in milk, J. Environ. Sci. Health B 29 (1994) 989-998.

[80] Scott P.M., Industrial and farm detoxification processes for mycotoxins, Rev. Méd. Vét. 149 (1998) 543-548.

[81] Schreeve B.J., Patterson D.S.P., Roberts B.A., The 'carry over' of aflatoxin, ochratoxin and zearalenone from naturally contaminated feed to tissues, urine and milk of dairy cows, Food Cosmet. Toxicol. 17 (1979) 151-157.

[82] Scudamore K.A., Livesey C.T., Occurrence and significance of mycotoxins in forage crops and silage: a review, J. Sci. Food Agric. 77 (1998) 1-17.

[83] Smith T.K., McMillan E.G., Castillo J.B., Effect of feeding blends of Fusarium mycotoxin-contaminated grains containing deoxynivalenol and fusaric acid on growth and feed consumption of immature swine, J. Anim. Sci. 75 (1997) 2184-2191.
[84] Spahr U., Walther B., Sieber R., Transfert des mycotoxines dans le lait: vue d'ensemble, Rev. Suisse Agric. 32 (2000) 75-78.

[85] Steyn P.S., The biosynthesis of mycotoxins, Rev. Méd. Vét. 149 (1998) 469-478.

[86] Swick R.A., Hepatic metabolism and bioactivation of mycotoxins and plant toxins, J. Anim. Sci. 58 (1984) 1017-1028.

[87] Tomasi L., Horn W., Roncada P., Zaccaroni A., Ligabue M., Battini F., Stracciari G.L., Recherches préliminaires sur la présence d'aflatoxine B1 dans les fourrages fanés de la province de Reggio Emilia (Italie), Fourrages 158 (1999) 179-186.

[88] Towers N.R., Sposen J.M., Zearalenone-induced infertility in sheep and cattle in New Zealand, N.Z. Vet. J. 41 (1993) 223-224.

[89] Trenholm H.L., Thomson B.K., Hartin K.E., Greenhalgh R., Mc Allister A.J., Ingestion of vomitoxin (deoxynivalenol)-contaminated wheat by non lactating cows, J. Dairy Sci. 68 (1985) 1000-1005.

[90] Westlake K., Mackie R.I., Dutton M.F., T-2 toxin metabolism by ruminal bacteria and its effect on their growth, Appl. Environ. Microbiol. 53 (1987) 587-592.

[91] Westlake K., Mackie R.I., Dutton M.F., Effects of several mycotoxins on specific growth rate of Butyrivibrio fibrisolvens and toxin degradation in vitro, Appl. Environ. Microbiol. 53 (1987) 613-614.

[92] Westlake K., Mackie R.I., Dutton M.F., In vitro metabolism of mycotoxins by bacterial, protozoal and ovine ruminal fluid preparations, Anim. Feed Sci. Technol. 25 (1989) 169-178.

[93] Withlow L.M., Nebel R.L., Behlow R.F., Hagler W.M., Browie C.F.G., Mycotoxins in North Carolina dairy feeds - a survey of 100 dairy farms, J. Dairy Sci. 69 (Suppl. 1) (1986) 223.

[94] Withlow L.M., Hagler W.M. Jr., Managing mycotoxin impact: An association of mycotoxins with production, health and reproduction in dairy cattle and guidelines for prevention and treatment, in: Lyons T.P., Jacques K.A. (Eds.), Proceedings of Alltech's 15th Annual Symposium, Nottingham University Press, Nottingham, UK, 1999, pp. 381-399.

[95] Whitlow L.W., Diaz D.E., Hopkins B.A., Hagler W.M., Mycotoxins and milk safety: the potential to block transfer to milk, in: Lyons T.P., Jacques K.A. (Eds.), Proceedings of Alltech's 16th Annual Symposium, Nottingham University Press, Nottingham, UK, 2000, pp. 391-408.

[96] Xiao H., Marquardt R.R., Frohlich A.A., Phillips G.D., Vitti T.G., Effect of a hay and a grain diet on the bioavailability of ochratoxin A in the rumen of sheep, J. Anim. Sci. 69 (1991) 3715-3723.

[97] Yoon Y., Baeck Y.J., Aflatoxin binding and antimutagenic activities of Bifidobacterium bifidum HY strains and their genotypes, Korean J. Dairy Sci. 21 (1999) 291-298. 